\title{
The Adoption of Interorganizational cost Management in a Vehicle Assembly plant in the Greater Region of $\mathrm{ABC}$
}

\author{
A Prática da Gestão de Custos Interorganizacionais em uma Montadora de \\ Veículos na Região do Grande $A B C$
}

\section{La Práctica de la Gestión de Costos Interorganizacionales en un Ensamblador de Vebiculos Automotores en la Región del Grande ABC}

\author{
Ana Cristina de Faria ${ }^{1}$ \\ Iderlan Charles Soares ${ }^{2}$ \\ Welington Rocha ${ }^{3}$ \\ George Bedinelli Rossi ${ }^{4}$
}

Received on March 12, 2012 / Approved on November 14, 2013

Responsible Editor: Ivam Ricardo Peleias, Dr.

Evaluation Process: Double Blind Review

\begin{abstract}
It is necessary that organizations define strategies for cost management in interorganizational relationships existing in the Supply Chain (SC), focusing not only on reducing individual costs, but on improviving the competitive advantage of these chains. The Interorganizational Cost Management (ICM) focuses on minimizing costs, creating competitive advantages in relation to competing chains. The objective of this study
\end{abstract}

\begin{abstract}
was to check how the ICM has been applied in the chain of an automotive assembly plant in the Greater Region of ABC (state of São Paulo). In conducting the exploratory research, we inquired of 10 managers in the areas of Procurement, R\&D, Supplier Quality Engineering, Logistics and Finance, to identify and analyze the aspects that characterize the practice of ICM in the assembly plant chain. We found that the ICM is adopted in all phases of the life cycle of the product, focused
\end{abstract}

1. Doctor in Controllership and Accounting from the University of São Paulo (USP) Professor at São Caetano do Sul City University (USCS). [anacfaria@uscs.edu.br] Author's address: Rua Santo Antônio, 50 - CEP: 09521-160 - São Caetano do Sul - SP - Brasil

2. Master in Management from São Caetano do Sul City University (USCS) Professor at Faculdades Metropolitanas Unidas (FMU). [iderlan.s@uol.com.br] Author's address: Av. Liberdade, 683, Liberdade - CEP 01503-001 - Sao Paulo-SP - Brasil

3. Doctor in Controllership and Accounting from the University of São Paulo (USP). [w.rocha@usp.br] Author's address: Av. Professor Luciano Gualberto, 908, Butantã - CEP 05508-900 - Sao Paulo - SP - Brasil

4. Doctor in Business Management from Getúlio Vargas Foundation (FGV/SP). Professor at São Paulo University and Escola Superior de Propaganda e Marketing (ESPM). [george.rossi@gmail.com] Author’s address: Rua Dr. Alvaro Alvim, 123, Vila Mariana - CEP 04018010 - São Paulo-SP - Brasil 
on cost reduction and continuous improvement of processes and products. The results show that the practice of ICM makes the relationships between the assembly plant and its suppliers more profitable and sustainable, and it is a tool capable of delivering benefits to the entire chain. Therefore, it should be included in the strategic management of companies.

Keywords: Automotive industry. Interorganizational cost management. Interorganizational relationships.

\section{RESUMO}

Faz-se necessário que organizações definam estratégias de gestão de custos em relacionamentos interorganizacionais existentes nas Cadeias de Suprimentos (CS), focalizando não apenas redução de custos individuais, mas a melhoria da vantagem competitiva das referidas cadeias. A Gestão de Custos Interorganizacionais (GCI) focaliza a minimização de custos, criando vantagens competitivas frente às cadeias concorrentes. O objetivo deste trabalho é verificar como está sendo praticada a GCI na cadeia em uma montadora de veículos automotores na região do Grande ABC (SP). No desenvolvimento de uma pesquisa exploratória, foram entrevistados dez gestores das áreas de Suprimentos, Pesquisa e Desenvolvimento, Engenharia de Qualidade de Fornecedores, Logística e Finanças, visando identificar e analisar os aspectos que caracterizam a prática da GCI na cadeia da montadora. Pode-se constatar que há prática da GCI em todas as etapas do ciclo de vida do produto, focadas na redução de custos e melhoria contínua dos processos e produtos. Os resultados obtidos evidenciam que a prática da GCI torna os relacionamentos entre a montadora e os fornecedores mais rentáveis e duradouros, apesar de ficar clara a dependência da maioria dos fornecedores e náo ficar caracterizada a transparência mútua. A GCI é ferramenta capaz de gerar benefícios para toda a cadeia, devendo ser incluída na gestão estratégica das empresas.

Palavas-chave: Gestão de custos interorganizacionais. Indústria automobilística. Relacionamentos interorganizacionais.

\section{RESUMEN}

Varios estudios bibliométricos se relacionan con métodos de costeo. Sin embargo, estos estudios son imprecisos en relación al período de revisión, lugar de publicación y socialización de los estudios analizados, corte longitudinal, entre otros temas de diseño metodológico. El objetivo de este estudio es recopilar y complementar los estudios bibliométricos presentados en Costeo Basado en Actividades, Costo Meta, Kaizen, Teoría de Restricciones y de la Unidad de Esfuerzo de Producción, sobre la base de datos de las primeras 17 ediciones del Congreso Brasileño de Costos (CBC). Similar a la trayectoria metodológica llevada a cabo por estudios bibliométricos anteriores sobre el tema, la investigación descriptiva se llevó a cabo con un enfoque cuantitativo, usando las técnicas de metaanálisis y análisis de contenido. Los resultados muestran que no hay una distribución normal en el volumen de artículos socializados en los últimos años, que el Costeo Basado en Actividades es el objetivo más buscado, seguido de la Teoría de Restricciones y, finalmente, aparecen juntos el Costo Meta, Kaizen y la Unidad de Esfuerzo de Producción. Los resultados también indican que los libros siguen siendo las principales fuentes de las referencias de los estudios sobre métodos de costeo. La naturaleza de la investigación se acercó en relación a los aspectos teóricos y prácticos, pero la investigación dirigida a los distintos métodos de cálculo de costos componentes de la muestra no están relacionados.

Palabras clave: Gestión de los costos entre organizaciones. Industria del automóvil. Relaciones interorganizacionales.

\section{INTRODUCTION}

New paradigms interfere in and change consumption and production practices, and change relationship and social structure dynamics (CASTELLS, 2001). Operating in an interorganizational network, the company is no longer observed individually, but in a context with 
one or more interconnected companies, and can therefore share resources, people and technologies, with a single way of working and with the same or similar strategies (DEKKER, 2003).

Interorganizational networks stand out for their flexibility and adaptability, and offer a new strategic and market view position, which enables more long-standing interaction between Supply Chain (SC) members through sharing of information and experiences, without compromising participants' independence (HOLWEG et al., 2005).

As the organization grows, stratification of management and span of control becomes crucial, and management of operations detach from strategic management. According to Borinelli and Rocha (2007), the Strategic Cost Management (SCM) does not boil down to actions seeking cost reduction: it refers to actions seeking improvement of the company's competitive advantage in broad terms. This is the new scenario in which, currently, most major companies have implemented cost management strategies focused on interorganizational relationships (KULMALA, PARANKO, UUSI-RAUVA, 2002).

Then, Interorganizational Cost Management (ICM) appears, focused on cost reduction in companies' SC, and increased profitability, through cooperation, collaboration and sharing of information among SC members (AGNDAL, NILSSON, 2009). This is an advanced tool to minimize costs and leverage profitability, focusing upon collaboration of the whole SC.

ICM is characterized as a SCM tool focused on minimizing costs and creating competitive advantages in relation to competing chains. According to de Souza and Rocha (2009, p. 21), "ICM is a cooperative cost management process that includes other organizations of a value chain other than the company itself." This process becomes a tool that can generate benefits to the whole chain, and should be included in companies' strategic planning and management (COOPER, SLAGMULDER, 1999).
Understanding the ICM requires changing the focus of analysis to the companies' value chain, focusing on value added (DEKKER, 2003). The value chain represents the activities performed to project, produce, sell, deliver and keep a product (PORTER, 1989). In this approach, the Value Chain concept is limited and focuses on activities conducted by companies' internally.

The ICM strategic approach is that the value chain concept should go beyond the company's internal space and include its business network (suppliers and customers), including the value system, and exploring higher return for both buyers and sellers, usually highlighting the optimization of the cost/effective relationship to the customer (SEURING, GOLDBACH, 2002).

Thus, exploring links of an external value chain requires knowledge of customer-suppliercustomer border activities, both upstream (suppliers' suppliers) ant downstream (customers' customers). In addition to this operational and logistics possibility, it is also possible to detect tax management leveraging opportunities (BORINELLI, ROCHA, 2007).

The increasing importance of this process has led researchers, such as Cooper and Yoshikawa (1994), Cooper and Slagmulder (1998), Cokins (2000), Goldbach (2002), Kulmala, Paranko and Uusi-Rauva (2002), Seuring and Goldbach (2002), Dubois (2003) and Agndal and Nilsson (2008, 2009, 2010), among others, to conduct studies which contribute for Cost Management to be performed beyond the firm's borders.

In these studies, it is believed that companies are required to define Cost Management strategies in interorganizational relationships. At the local level, we can also point out the studies conducted by Aguiar, Rezende and Rocha (2008), Souza (2008), Souza and Rocha (2009), Camacho (2010), Facci (2011), Faria et al. (2010) and Nascimento and Pereira (2011), among others.

As an explanation for selecting the automotive industry as the subject matter of the research, we point out the importance of this segment for the Economy and its ongoing changes 
in the past years. It is still considered a major activity the world over (WOMACK, JONES, ROOS, 2004).

Given all these changes, over the past few years, the production process of automotive industry was greatly restructured. The "old" independent small structures or major vertically integrated companies cannot meet the new challenges (CARMO, HAMACHER, 2001).

Accordingly, new Supply Chain mechanisms needed to be developed for the growth route to continue, and the segment, according to Holweg et al. (2005), has been through an expansion of interorganizational relationships and strengthening of partnership among the automotive industry chain, which explains why this segment is the focus of our study.

Based on the foregoing, the question on which this research is focused is How is Interorganizational Cost Management practiced in an automotive assembly plant in the Greater Region of ABC (ABC stands for Santo André, São Bernardo do Campo and São Caetano do Sul, all cities in the state of São Paulo, Brazil)? In order to reach an answer to our question, we need to study the relationship between the automotive assembly plant and its first-level suppliers in their SC, as regards operational, financial and even technical information sharing over the production process. The general objective of this research is to check how the ICM is practiced in an automotive assembly plant in the Greater Region of ABC.

The ICM is a growing topic in the world. Cooper and Slagmulder (1999) work is a pioneer in international-level Management Accounting, and therefore is greatly cited over throughout this paper. In Brazil, Bitti, Aquino and Pagliarussi (2007) comment on cost monitoring in business networks and the Agency Theory; but the first reference concerning interorganizational management control, which effectively refers to ICM, is found in Souza (2008) master's thesis in 2008.

Ever since, at local level, some work on the topic has been conducted by Aguiar, Rezende and
Rocha (2008), Souza (2008), Souza and Rocha (2009), Camacho (2010), Faria et al. (2010) and Nascimento and Pereira (2011), among others.

We believe that the rationale for this study is that it is expected to contribute, based on empirical research in a significant segment of the Economy, the automotive industry, to expand and deepen the level of knowledge existing of strategic management, business networks and interorganizational relationships, in addition to Management Accounting. We expect that this work will contribute to enrich the debate on the aforementioned topics, so as to leverage or keep companies or networks' competitive advantage.

\section{THEORY}

\section{I Interorganizational relationships in the automotive production chain}

One of the main characteristics of the current business environment is the need for organizations to operate in a joint and associated manner, in a business network, and share all kinds of resources by defining specific strategies. This trend has led companies to set cooperation relationships, eliminate the boundaries that limited them, form chains, conglomerates, networks and alliances (MOURITSEN, THRANE, 2006).

Changes in the automotive industry forced assemblies' suppliers to adjust their processes to meet the new requirements, and modify production chain structure, which requires that the activities performed by them be more coordinated, and that chain members be more integrated (STURGEON, BIESEBROECK, GEREFFI, 2008)

This situation requires that companies adopt quick measures to meet business needs, which has responded to this demand by adopting a decentralized organizational structure based on work groups. Managers need to perceive the different operation focuses, constantly influenced by changes, by analyzing the activities performed 
by the company and its partners, and leading to quick delivery, volume flexibility, delivery trustworthiness and product differentiation (CHILDERHOUSE et al., 2003).

The SC is a network section and, according to Cox, Sanderson and Watson (2001, p. 28), it is "a network of dyadic exchange relationships that must exist for the creation of any product or service that is supplied to a final consumer." Relationships within a given social field (dyadic), in the case of SC, between company, suppliers and customers, are required for the production of goods or services to exist, so that the final customers can have their needs met and the advantage competitiveness can be ensured.

With the increase in competitiveness, the interaction process propels new challenges and opportunities for the organization and management of the production process; the relationships in companies' SC are intensified and companies start to share operational, economic and financial information in order to become more competitive and sustainable (MYERS, CHEUNG, 2008).

Lambert, Garcia-Dastugue and Croxton (2005) and Bowersox, Closs and Cooper (2005) state that the SC tends to be multiple and integrated, and share resources, risks and costs. A major driver to be observed by partners within the $\mathrm{SC}$ is the change in culture regarding the strategic focus, as this is not related to the lowest price, but the lowest cost.

With an integrated approach of each link in the SC, organizations are expected to obtain significant competitive advantages, through cooperation and collaboration, which materializes through sharing of information, such as cost and outcomes, which are included in the ICM base (COOPER, SLAGMULDER, 1999).

Companies are increasingly seeking cost reduction over the production process. Souza and Rocha (2009) point out that, in a strong competition scenario, companies cannot minimize costs based on internal aspects only, but must adopt a strategic cost view, which contemplates companies with which they are related. This refers to SC, as mentioned by Cokins (2000).

Upon analyzing their SC, companies should consider the importance of the relationships between customers and suppliers over the several production levels. In the automotive industry, on which this study is focused, as in any other industry, strengthening relationships among production chain members is fundamental for the sharing of information and reduction of costs (STURGEON, BIESEBROECK, GEREFFI, 2008).

Coad and Cullen (2006) reinforce that enhancing relationships among companies in a chain may lead to cost reduction and creation of value. In order to perform this analysis, we need a deep study on the relationships of the companies participating in a chain, which highlights the importance of having a joint Cost Management in interorganizational relationships.

The definitions and positions of the several aforementioned authors evidence the importance of issues related to costs incurred in interorganizational relationships, mainly in connection with the collaborative behavior among members of a SC, which advocate the need of an ICM.

\subsection{Interorganizational Cost Management (ICM)}

Research on interorganizational relationships focusing on management controls has increased considerably since 1999. Mouritsen, Hansen and Hansen (2001), Hakansson and Lind (2004), Dekker (2004) and Caglio and Ditillo (2008), among others, studies the evolution of management control mechanisms connected with interorganizational relationships. These authors attempt to understand how control problems emerge, the interaction with the control project, and the environment in which the relationship exists.

Integration among companies operating jointly in an SC has led to the need of broader 
Cost Management, based on the search for means to coordinate and share information, which has encouraged the development of interorganizational relationships with a higher level of intercompany interdependence (AGNDAL, NILSSON, 2008).

Companies are increasingly seeking to minimize costs throughout the production process, and are expected to obtain significant competitive advantages by means of increased service levels and reduced inventory and storage costs. This, however, can only be achieved if there is actual cooperation and collaboration, which materializes through sharing of physical and operational information, as well as financial and economic information, such as costs and outcomes, which are the base of ICM (COOPER, YOSHIKAWA, 1994).

Literature on Strategic Management Accounting and Strategic Cost Management (SCM) has mostly presented work with the existence of collaboration, which allows researchers to not only analyze the processes in which value is added by the company, but the overall production chain, and investigate the antecedents and consequences in the SC or in business networks, as Simmonds's (1981), Mouritsen, Hansen and Hansen's (2001), Dubois's (2003) and Hakansson and Lind's (2004), among others.

The perspective gaining attention in the business world is the idea that Cost Management can be applied to the whole SC. Companies need to develop strategic partnerships in several aspects, mainly in connection with Cost Management (GIANIASELLA, SOUZA, ALMEIDA, 2008). Mutual cooperation and sharing of risks are fundamental elements to achieve chain or business network objectives, and if companies, members of such chain, operate individually, they will achieve their individual goals, but will not share significant risk nor will they be mutually committed (MYERS, CHEUNG, 2008).

Not only does the SCM lead to improved performance by the companies, but it also encourages cost management, which requires focus on aspects outside the company. This has become a support element to the integration of the production chain in all its phases (SEURING,
2002). The scope of cost management in a chain should comprise all process phases, which results in a model that exceeds organizational limits and that can involve suppliers and customers (GOLDBACH, 2002; KULMALA, PARANKO, UUSI-RAUVA, 2002).

The most important point in SCM view is explicitly relating Cost Management to the business strategy, as well as the competitive context in which value is added to the customer. SCM leverages the links established for both customers and suppliers, which expands information on costs. This includes external aspects and is not limited to simply calculating the cost of products (SHANK, GOVINDARAJAN, 1997).

According to Caglio and Ditillo (2008), the SCM is quite important in interorganizational relationships, mainly focusing on management of risks in specific transactions, and coordination of exchange of activities by means of organizational boundaries.

The SCM strengthens the relationship between companies by means of a cooperative information management process, particularly in management of costs in a strategic manner. The ICM can be used in the whole production process, from basic raw material sources to component suppliers to the final product delivered to the final consumer (AGNDAL, NILSSON, 2009).

Shank and Govindarajan (1997) defend that companies should be seen as part of a global chain, and that value is generated over several companies and not necessarily one. This analysis is considered critical and required in order to understand ICM. Indeed, according to Mouritsen and Thrane (2006), the study on value chain, in the ICM context, better describes the interorganizational relationships and provides an analytical framework to enhance the profitability management of companies, SC or business network. The ICM seeks to consider this new scenario.

Souza and Rocha (2009, p. 132) define ICM as "a cooperative cost management process which includes other organizations in a value chain other than the company itself." With 
the ICM practice, companies expand their relationships and share significant information on costs with the opening of their books of account. These authors focus the main issue of their research on the lack of a conceptual model on ICM and detect that there are five conditions precedent for the ICM: type of chain, products, components, relationship levels, and mechanisms. These factors will be described later in this paper, in Chart 1.

The ICM can be considered an innovative contribution to the academic literature and to the fostering of corporate competitiveness. For business practices, the ICM probably reaches higher benefits, and leverages outcomes in a context of global production chains and world-class manufacturing. This is the primary mechanism of the company used to manage suppliers' costs. Therefore, it should be applied to the product in all production phases, from design to manufacturing (COAD, CULLEN, 2006).

Its comprehensiveness should not be limited to the company's walls, i.e., it should reach the whole $S C$, and create significant synergy among chain members in order to reduce costs. It enables these members to find solutions by means of coordinated actions among chain companies, which would not be possible if companies attempted to reduce costs independently (DUBOIS, 2003).

According to Cooper and Slagmulder (1999), the ICM is intended to reduce costs in the network, increase profitability and share additional gains among companies of the referred to network, in addition to creating and keeping cooperative actions among these members. In fact, the ICM breaks the paradigm of research focusing on the corporate unit, and scales the analyzed to the supply chain or business networks as the unit of interest (COKINS, 2000).

Implementing the ICM involves a set of variables, such as strategic position, use of SCM instruments and sharing of information on the costs of the production process and on the outcomes among network participants (players). This is an advanced practice in cost management, with a collaborative profile and focus on product cost reduction, but particularly on increasing business value and product profitability (COOPER, SLAGMULDER, 1999).

Coad and Cullen (2006) reinforce the view of these authors, as they understand that enhancing relationships among companies in a chain may lead to cost reduction and creation of value. In order to conduct this analysis, we need a deep study on the relationship of companies participating in the chain.

As regards the focus, according to Cooper and Slagmulder (1999), the ICM can minimize costs in three different areas:

- the first on within organizational limits during product design, phase in which the ICM is structured to coordinate the development of the product, with interfaces among most efficient companies based on the Target Costing;

- the second one is related to product manufacturing. Here, the interorganizational Kaizen Costing is used to coordinate the activities in the production chain, so products and components can be constantly produced and enhanced, an new forms of design can be discovered, and

- the third one focuses on the company's helping its suppliers discover new ways to reduce product costs during production.

From an ICM perspective, according to Mouritsen, Hansen and Hansen (2001), companies have developed Cost Management techniques, such as Target Cost, Value Engineering and ICM systems. These systems demonstrate that most costs of product are created at the beginning of its preparation. In this phase, the following concepts are prioritized: Value Engineering, FunctionalityPrice-Quality (FPQ), trade-off, Interorganizational Cost Investigation (ICI) and Parallel Cost 
Management or Simultaneous Engineering.

Value Engineering (VE) involves an interdisciplinary and systematic review of the factors affecting the cost of a product, so as to conceive means to reach the quality and trustworthiness level of the Target Costing. The VE, as well as the Target Costing, is applied during the development of the product and play a critical role in future product cost management (LORANDI, 2009).

As regards trade-offs, Shank and Govindarajan (1997) argue that the SCM is characterized by the use of cost data to develop and detect strategies, by analyzing the main links generated based on these trade-offs by companies in the SC. The FPQ trade-off applied in the interfaces between buyer/supplier plays a key role in ensuring that all companies in the SC are profitable (COOPER, SLAGMULDER, 2003).

According to Lorandi (2009, p. 8), "the interorganizational cost investigation (ICI) intends to redesign products and components, so they can be manufactured at their Target Costing." Supplier and buyer work together to change the design and reduce costs in the SC. The Parallel Cost Management or Simultaneous Engineering (SE), on the other hand, involves simultaneous cost management activities between company and its supplier, in the scope of changes in design that can be implemented together with these suppliers, in order to detect additional cost reduction opportunities (COOPER, SLAGMULDER, 2003).

Once the product is in the production phase, it is harder to reduce costs, but through operational control and product cost measurement, it ongoing improvement is possible. The life cycle of a product has three phases: development, planning/design and production. The Kaizen Costing is used in the product manufacturing phase and aims at ongoing improvement (MONDEN, 1999). It is a cost enhancement tool that should be used during the whole production process, and intends to enhance the phases in this process during execution (LORANDI, 2009).

We should point out that costs managed individually may lead to cost reduction, but not necessarily leverage and add value to the overall chain. The ICM, on the other hand, develops cost management focused on global cost minimization, which creates competitive advantages before competing chains (SOUZA, ROCHA, 2009). Kajüter and Kulmala (2005) and Kulmala, Kajüter and Valkokari (2007) explain that the factors inducing ICM among companies are contingent. Souza and Rocha (2009) classify factors that are conditions precedent for ICM into five items that can be seen in Chart 1:

\begin{tabular}{|c|c|}
\hline Conditions precedent & Characteristics \\
\hline Product & Profit margin \\
& Functionality \\
\hline Component & Technology \\
& Value index \\
\hline \multirow{2}{*}{ Relationship level } & Common \\
& Ancillary \\
& Principal \\
& Familiar \\
\hline Type of chain & Tyranny \\
& Oligarchy \\
& Democracy \\
\hline Mechanism & Disciplining \\
& Enabling \\
& Encouraging \\
\hline
\end{tabular}

CHART 1 - Factors that are conditions precedent for ICM

Source: Adapted from Cooper and Slagmulder (1999)

As regards the product, we need to detect what type is recommended for the ICM application, with highlights given to two major characteristics: margin and product functionality (SOUZA, 2008). Products with low margins need more cost management, which expands the possibility of ICM application. As in the case of the margin, product functionality decisively influences the ICM application.

In the following paragraphs, the factors that are conditions precedent included in Chart 1 , as well as their characteristics, will be commented, mainly based on Cooper and Slagmulder (1999) work, which is the pioneer and one of the most significant in the field. 
The functionality level is related to the number of product specifications. The more specifications of a product, the larger is the field of cost management possibilities, beyond the boundaries of a company (SOUZA, 2008). In this fertile field, in which there are effective interorganizational relationships between a company and its suppliers or customers, the ICM can provide appropriate cost management and reduction (KAJÜTER, KULMALA, 2005).

As regards the components of a product, ICM application is not required for all of them. Its application should focus on key components, in order to detect which should be monitored. The company needs to consider two significant characteristics: technological reliability and value index.

The value index links the cost to the resource importance level. The lower the value index, the higher the cost, which makes ICM application more necessary. This analysis helps in choosing components that need to be used by ICM. The relationship between chain members, on the other hand, can be construed in four levels: Common, Ancillary, Principal and Familiar.

The Common relationship is weak and with low dependence; the Ancillary relationship is a bit more dependent. By identifying the product, the relationship gets closer, which leads to more stability in keeping suppliers. This type of relationship requires no conduction of research with partners: the company shares product design and guidelines for production with its suppliers. The relationship with suppliers is Principal when the relationship is more integrated with the company and the stability and reliability levels and benefit distribution between the companies are much higher, as they share knowledge from product development on.

The relationship with suppliers is Familiar when interdependence reaches the highest level. The supplier works directly in the company, and usually shares information, technologies and even employees; the one in charge of the project of the product or components is usually shared with the supplier (KAJÜTER; KULMALA, 2005). This type of relationship encourages research, from the first life cycle of the product, focusing on product enhancement. The higher the relationship level existing between companies, the greater the possibility of fully implementing the ICM.

As regards the type of chain, Cooper and Slagmulder (1999) detected three perspectives: Tyranny, Oligarchy and Democracy. This segregation is established based on the number of companies dominating the chain, as follows: Tyranny - a single company dominates the chain and determines how relationships take place and sets the roles for reach one involved in the process; Oligarchy - power is distributed between two or more companies, with clear separation between dominating companies and the others; and Democracy - there is no dominating company or group of companies.

As regards Disciplining, Enabling and Encouraging mechanisms of the ICM, according to Souza and Rocha (2009), they are instruments that help managing cost in order to guide, control, measure, report and provide standards, which makes ICM application possible. Disciplining mechanisms can regulate interorganizational actions and should be used as a bonus measure for organizations which stand out in their obligations (SOUZA, 2008). The purpose of these mechanisms is to transfer the pressure related to cost management to the whole chain, and therefore leverage return to its members.

The Enabling mechanisms are instruments that foster the ability of chain members in order to solve any difficulties in executing the ICM. The purpose of these mechanisms is to collaborate with chain companies, in order for them to achieve their cost reduction goals, and combine skills and efforts of those involved in the process.

The Encouraging mechanisms regulate the distribution of benefits generated by the ICM. According to Souza and Rocha (2009), these mechanisms can be considered managerial instruments supporting the ICM. Bisbe, BatistaFoguet and Chenhall (2007) developed a critical argumentative analysis on the topic, as in Figure 1 below: 


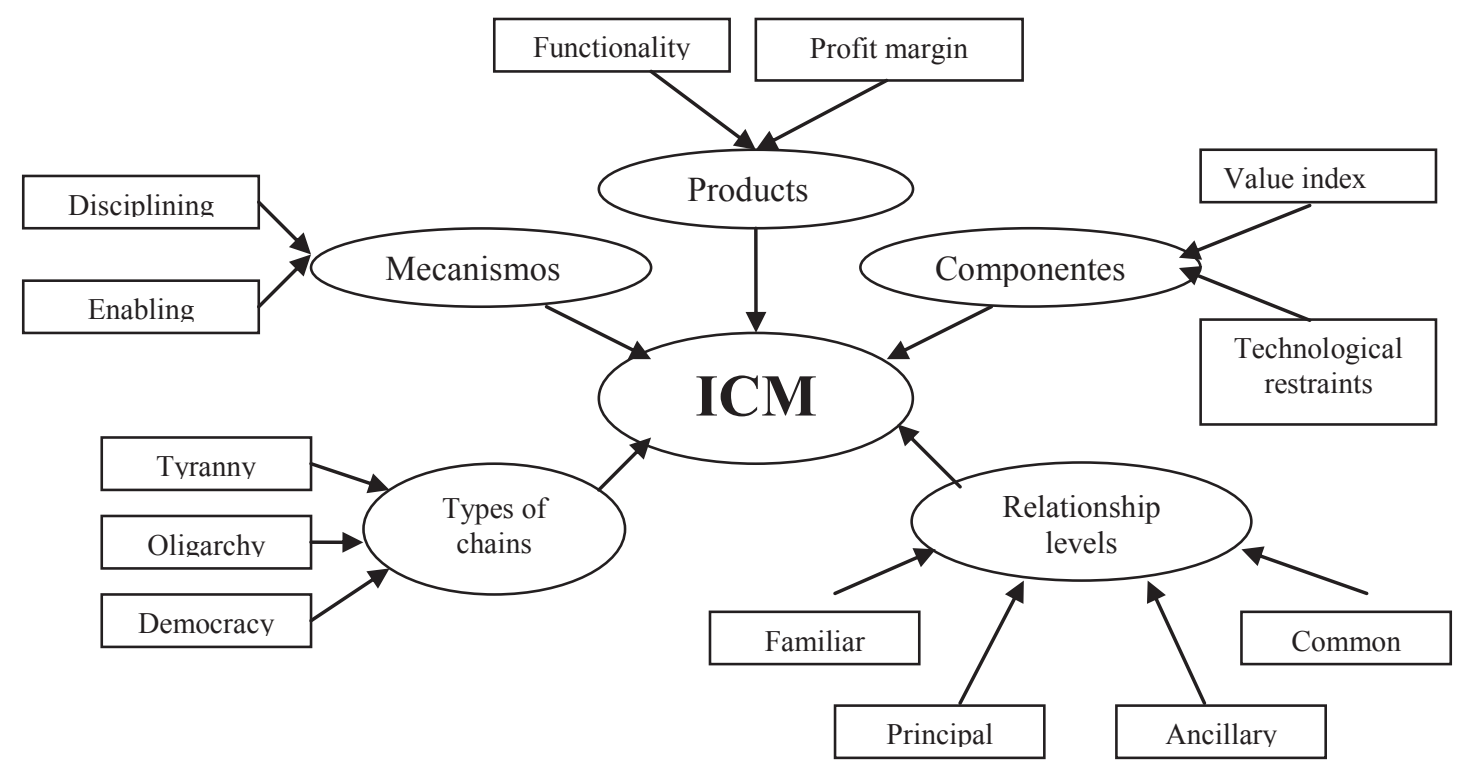

FIGURE 1 - Specific contingent variables of the network and potential for implementation and use of the ICM

Source: Adapted from Bisbe, Batista-Foguet and Chenhall (2007)

The logics presented in Figure 1 does not allow visualization of all factors that are conditions precedent for the ICM. According to Souza (2008, p.75), this model "is not an answer decision tree," but a set of possibilities that may help take decisions more reliably. Thus, the five dimensions mentioned above represent a conceptual framework for the ICM, and this is an overview of management possibilities and dimensions thereof.

Souza (2008, p. 17) points out that the dimensions defined are based on an analysis and understanding of how they are "presented, classified and discussed." Souza and Rocha (2009) argue that the profit margin, technological restraints and value index as factors that are conditions precedent may foster or discourage the use of the ICM. According to Camacho (2010), as regards the profit margin, the idea of Souza and Rocha (2009) is related to that of Kajüter and Kulmala (2005), when they suggest that the market "competitiveness level" can put pressure on costs and affect profit margins.

According to Kulmala, Paranko and Uusirauva (2002), Cost Management that produces unreliably data becomes an obstacle to using the ICM. Another important variable is the commitment to cost reduction in the long run (KAJÜTER, KULMALA, 2005). This view contributes to the development of trust among value chain members. Therefore, information sharing and cost control in the SC are required. In the following topic, we will present the methodological aspects used in this research.

\section{METHODOLOGICAL ASPECTS}

Based on the objective established, we have conducted an exploratory research, based on a qualitative database. One of the main characteristics of a qualitative research is the predominance of description, whether of people, scenarios, events, relationships or report transcripts (GIL, 2009).

Under the perspective adopted by Richardson (1999, p. 281), "exploratory research seeks to investigate the characteristics of a phenomenon and look for explanations for causes and consequences of such phenomenon." This type of research seeks to provide more knowledge to the researcher of a matter, so that the researcher 
can formulate more accurate problems or create hypotheses that can be researched in future studies (GIL, 2008).

According to Ponte et al. (2007), the exploratory research focuses on the issue to be resolved, in order to make them more explicit and enhance ideas. According to these authors, this type of research is flexible, usually of a qualitative nature, in the sense that any aspect related to the fact studied is significant and can involve document analysis and inquiries of people who have experience in the problem to be solved. This is what we did in this research.

This qualitative study was conducted from November 2010 to March 2011 and is limited to an automotive manufacturing company (assembly plant), located in the Greater Region of ABC (SP). This industry was chosen for its importance in the Brazilian economy, and the company, for its size and billing. This is not characterized as a business case, for the assembly did not authorize researchers to access multiple sources of evidence (CRESWELL, 2010).

In an agreement with the company, the researchers entered into a nondisclosure agreement, with the company and respondents, which is duly signed by both parties - the researchers and the company. Data was collected through personal inquiries of ten executives, managers and officers, of the Procurement, R\&D, Supplier Quality Engineering, Logistics and Finance functions.

Inquiries of the aforementioned managers, which were conducted by the researchers themselves, were based on a research instrument already validated in a research conducted by Cooper and Slagmulder (1999), through the questions contained in item 4.2 of this article.

The inquiries focused on the relationship between the assembly plant and its first-level suppliers, at the several phases of the product life cycle, from conception to product discontinuity. These inquiries could not be recorded in order to preserve information made available in an environment outside the company.

Therefore, information obtained was written down by the researchers. The respondents provided us with no spreadsheets or documents that could be published outside the company. Through direct observation during the inquiries, some spreadsheets and documents were shown and detailed to the researchers, who wrote down the most significant points.

\section{DESCRIPTION AND ANALYSIS OF RESULTS}

\section{I The assembly plant and the interorganizational relationship with first- level suppliers}

The global automotive industry is divided into two major production complexes: assemblies and auto part suppliers. The industry has always been marked by a small group of assembly plants and by a large number of auto part suppliers with long-term agreements and superficial relationships between suppliers and assembly plants (AMATO NETO, 2000). Today, this relationship has changed a lot and a lot of information is exchanged in the whole SC of the industry companies.

The region focused by the field research is the Greater ABC, in the state of São Paulo, for it concentrates the highest number of assembly plants and auto part manufactures in Brazil (XAVIER, SOUZA, BRESCIANI, 2007). The assembly plant selected for this study did not authorize us to disclose its name. Its branch/head office in Brazil is located in the Greater Region of $A B C$ (SP). With its head office in the United States, it employees 209 thousand people in major regions in the world; it operates in more than 120 countries and produces vehicles in 31 countries, selling and providing services for several makes of vehicles.

The 2,200 suppliers of the assembly plant are chosen based on the following items: Supplier costs: meets the comparative study between assembly plant internal cost and supplier cost; Quality: the supplier must meet the quality standards required by the assembly plant, and supplier's know-how (technology, ability etc.). Approximately 780 companies are active 
suppliers of direct materials. The company trades in the region of 4,000 to 4,500 items (SKUs) with suppliers. The partnership with suppliers involves issues such as Costs, Quality, Technology, Information Systems, Processes, Resources (Assets) and People.

In the Bidders List, i.e., in the process of choosing a supplier (Tier 1), some requirements are considered, such as quality, service level, technology, flexibility, warranty, material flow and logistics (just in time/milk run delivery), human resources, economic and financial position of the supplier and price formation, which are the main items considered by the assembly plant in selecting and forming its group of suppliers. These items are analyzed through forms filled out in visits paid periodically by the Supplier Quality Engineering (SQE) department to each supplier.

Through a preliminary assessment, the risk level that each supplier may represent for the company is defined. Above $30 \%$ of risk, the supplier may not proceed in the selection process. It is important to point out that the supplier's financial position is analyzed through the financial statements produced thereby and consultations with several credit protection agencies to check its good standing and payment capacity. We detected that $60 \%$ of the problems with suppliers are related to economic and financial issues and approximately $40 \%$ are related to operational issues. The company considers that it better have profitable suppliers, in order to ensure supply.

Professionals who already have a long-term relationship with the assembly plant to supply parts are preferred in the selection, as this indicates that they are able to serve a large company. The company's contact is with Tier 1, and possible contacts with other level suppliers are only in the $R \& D$ phase to ensure quality of items.

In the product life cycle, partnership with suppliers starts at project conception and continues through the vehicle production process, as advocated by Dekker (2003). The assembly plant conducts a pre-study to analyze project feasibility (cost / time / investment), designs its configuration (simultaneous engineering / co-design / target costing), conducts a validation procedure (test) and, at last, starts the production process.

The assembly plant's objective in the $\mathrm{R} \& \mathrm{D}$ phase is to obtain a set of information to support decision taking as to the project feasibility and economic and technological benefit generation to the assembly plant itself and its suppliers, as commented by Holweg et al. (2005). In the project configuration phase, the assembly plant analyzes the level of simultaneous engineering, codesign and target costing, which are very significant elements to leverage value generation (see topic 2.3).

With the simultaneous engineering and codesign, the assembly plant can integrate product development structure, and thus reduce lead time, of operating costs and cycle times. Therefore, suppliers' involvement and commitment of all function involved are necessary (Design, Production Engineering, Logistics and Finance, among others), in order to determine the desired improvements and intervene in the whole flow of the process, by controlling the implementation phases, as suggested by Dekker (2004).

Then, a Statement of Requirements - SOR, which defines the requirements or assumptions that must be met by potential suppliers participating in the sourcing process. This assumption involves technical, quality, performance, flexibility, environmental and cost issues.

After the sourcing process tooling construction, as well as the technical and technological development of the referred to suppliers, is monitored.

In partnership with its suppliers, the company estimates the target cost of a product, so that, given the sale price offered by the market, it is possible to reach the profitability level established, as suggested by Seuring (2002). This mechanism involves, as seen in theory, a Strategic Cost Management process used to reduce total costs in the product planning and design phases, as advocated by Mouritsen, Hansen and Hansen (2001). 


\subsection{ICM at the vehicle assembly plant}

In this section, we describe significant evidence that may characterize the ICM practice in a vehicle assembly plant, as developed by Cooper and Slagmulder (1999), based on the responses obtained in each question asked to the ten executives, managers and officers of several functions, as mentioned in item 3 hereof.

\section{1) Does the company make its relationship} with suppliers more efficient? If yes, how?

All assembly plant executives answered yes. Main suppliers (tier) participate in operational and strategic activities, such as product R\&D, and share several pieces of operational information regarding the purchase order, programming, order confirmation and demand forecast. On its communication portal (EDI via Internet) with suppliers, information is available online, which allows greater interaction with suppliers. We may conclude that the relationship of the assembly plant with its suppliers is well integrated and has a high level of stability and reliability.

2) Is cost information available to the suppliers?

Believing that the sharing of information and joint planning can reduce costs in the SC, executives reported that the exchange of information on costs begins at the product $R \& D$ phase and continues until the production phase, according to Dubois (2003).

In practice, what exists is a requirement by the assembly plant to its suppliers to breakdown the cost of components provided with all the details of cost of materials, direct labor (hourly rates) and the appropriate manufacturing overhead of the products, as well as the profit margins of each item, such as that obtained in the research conducted by Kajüter and Kulmala (2005).

Mechanical engineers of the assembly plant are in charge of technical, economic and financial analyses of the cost of materials supplied and of any changes in prices. There is no mutual transparency, as the assembly plant does not breakdown its economic and financial information to the supplier.

3) What information (reports) is made available by the assembly plant to its suppliers?

For a strategic reasons, the assembly plant does not report which reports are disclosed to its suppliers. Information shared between the assembly plant and its suppliers involves technical aspects (technical review) of new product projects, in which suppliers are called for the sourcing phase (bidding). In this phase, suppliers form their prices for the components required, based on the assumption presented in the sourcing process.

When asked in relation to the inventories, the assembly plant executives state that the plant does not provide this kind of information to its suppliers, as commented by Childerhouse et al. (2003). They report that there has been substantial reduction of the time elapsed from assembly plant order to the delivery of products in its production line, as information on input cost and the logistics process in the SC is shared with the suppliers.

4) Does the company help its suppliers and customers find ways to reach their cost reduction objectives? If yes, how? Through which controls?

The assembly plant executives indicated that the integration and cost reduction in the SC are subject to the consolidation of the number of suppliers, qualification and development of these partners, in order to reduce costs and generated benefits to the SC members, as suggested by Holweg et al. (2005).

The collaboration of the assembly plant and its suppliers can range from an informal evaluation of their procedures and operations to development of a program of joint investment in training and improvement of products and processes, among others, to maintain a high level of efficiency in all phases of the production process, as described by Sturgeon, Biesebroeck and Gereffi (2008).

The assembly plant requires and contributes to improvement and implementation, with its suppliers, of items such as financial health - transparency of costs and investment capacity; 
Certification (ISO 9000 e QS 9000) and audit systems of the assembly plant itself; Electronic integration; Joint development of new products, processes and systems, segregation of duties/ risks/gains; Standard of cost, quality, quantity and price; Logistics - reliability and delivery term; Waste reduction - waste, defect and zero inventory.

Help to suppliers through programs and increased participation in the decisions taken in relation to the development of products leads to considerable cost reduction, according to an assembly plant executive. Most first-level suppliers of the assembly plant also have such requirements to their direct suppliers.

5) What significant cost-related information is required from the supplier in a new product project in the R\&D phase?

The assembly plant develops R\&D activities with its suppliers under an agreement. For each project, whose development lasts about six months, a group of technicians of $\mathrm{R} \& \mathrm{D}$ and areas related to the assembly plant and suppliers' project.

Several projects are developed simultaneously and many of them are motivated by: a) new technology development, many times by the assembly plant/supplier partnership; b) innovative solution for problems brought by the assembly plant's internal and outside customers, and c) social interaction: technological innovation arising from interaction between people in other departments and/or institutions.

In the $R \& D$ phase of new products, the assembly plant seeks to leverage processes and reduce costs, by requiring and analyzing information such as evaluation of alternative products or processes; conception, construction of prototypes, models and pre-production; conception of tools, devices and development of new technologies.

The assembly plant requires that its suppliers apply the Target Costing system, as suggested by Mouritsen, Hansen and Hansen (2001) and Seuring (2002), and requests price forecast spreadsheets to its suppliers so that, together, they can determine the highest cost the supplier can incur without compromising its results. This suppliers' submission characterizes what Porter (1989) defined as "economic power," in which suppliers and customers can influence the ability of a company to reach economic success.

6) What cost-related information is required to the supplier when a product is already in the production line?

In this phase, the assembly plant encourages its suppliers to implement the Kaizen Costing, as suggested by Monden (1999), in order to reduce costs in all product production phases. In addition, it seeks interaction with suppliers in order to develop techniques and new practices which reduce costs in the production phase.

It also keeps permanent control over material management processes of tis major suppliers, and requests permanent inventory of materials and products, reports on the programming and control over production, in order to help suppliers to take adjustment actions during the whole period in which their commercial relationship is expected to exist. Therefore, it will reduce costs in the chain, as suggested by Cokins (2000) and Agndal and Nilsson (2010).

7) Do the companies in the network share employees, RoD and investments? How are these shared?

As mentioned in previous questions, the assembly plant and its key suppliers share not only information, but also employees and investments, which corroborates what was advocated by Cooper and Slagmulder (1999). The assembly plant and suppliers conduct research and prepare new products in order to seek new knowledge of products and processes, as suggested by Mouritsen and Thrane (2006). Suppliers' employees are requested to work in the assembly plant technology center in specific projects and monitor the vehicle production processes in the plant.

On the other hand, assembly plant employees, from the Supplier Quality Engineering 
function, also monitor the production line and development centers of its suppliers. Research conducted in conjunction encourage participants to contribute even more, as such interaction enables constant update of processes, and development of employees participating in the project. Cost reduction in the SC has also encouraged the assembly plant and its suppliers to conduct joint studies, as suggested by Seuring and Goldbach (2002).

8) Does the company conduct research on competing product costs? If yes, how?

Competitors' cost-related information is of paramount importance for the development of any business. The assembly plant and its suppliers monitor their competitors, as suggested by Cooper and Slagmulder (1999). This is achieved through reverse engineering, i.e., by purchasing competitors' products and breakdown of the referred to products by the Engineering functions to check the origin and functionality of the components used and, as a result, estimate their costs.

9) Is there a transparency practice for economic and financial information? If yes, how? Which reports and instruments are used?

In negotiations with the assembly plant, there is a culture to breakdown spreadsheets, as suggested by Agndal and Nilsson (2008; 2010). From $90 \%$ to $95 \%$ of suppliers breakdown their spreadsheets; the others do not, mainly due to technological and competitive advantage questions.

For several types of analyses, spreadsheets contain detailed prior-year, budget, budget forecast, current-year information, so possible gains shared between the company and first-level suppliers can be checked. The assembly plant does not share its economic and financial information with its suppliers, which characterizes the chain as a "tyranny," according to Cooper and Slagmulder (1999).

When the assembly plant is analyzing its suppliers' cost spreadsheet, in addition to technical, economic and financial aspects (cost of materials, direct labor (hourly rates), manufacturing overhead and profit margins), it also analyzes whether suppliers' professionals computing the costs have been through higher education or post-graduation, whether the suppliers' cost management is sustainable, i.e., relies on good theoretical grounds, and use consistent costing methods.

It is also checked whether there is remuneration (profitability) and continuity of operations by the suppliers, whether costs are competitive in relation to the market, and whether the company has invested in plant infrastructure and renovation. There is no such analysis by the suppliers, as the assembly plant has the bargaining power and does not share its economic and financial information, as mentioned above.

10) Does the company use Value Engineering in order to increase value (product function) and reduce cost?

In preparing a new product, or even when manufacturing it, the value and role it will play for consumers need to be measured. The development of a new vehicle requires the understanding of a number of functionalities of such product and of standards to meet market demands. The Value Engineering reviews each component of a product, in order to detect its functionalities and performances, as well as its costs.

According to the ten executives surveyed, officers and managers of the Procurement, R\&D, Supplier Quality Engineering, Logistics and Finance functions, the evaluation criteria of a project are too comprehensive. A product is developed considering all its functionalities and the possibility of expanding them, in addition to reducing cost in its life cycle, as mentioned by Kulmala, Paranko and Uusi-Rauva (2002).

The production of modules or systems increased considerably the functionalities of products delivered to the assembly plants, as well as their value added. The assembly plant holds periodic meetings with its suppliers to discuss and find solutions in this sense. 


\section{1) Does the company encourage development} of new ideas to reduce costs? If yes, is this reduction passed on to product price?

Not only does the assembly plant encourage creativity of its employees, but it also encourages this practice in its suppliers through awards and certifications. To encourage creativity of its partners, the company holds workshops to generate ideas. These meetings result in generation of ideas for permanent cost reduction, specific actions and planning for the implementation of these ideas.

After solving a number of cost reduction issues, the solution for each one can be used to generate new ideas and solutions to other issues, as well as, at some times, even to reduce the price of the final product and increase competitiveness of companies in the SC, as suggested by Coad and Cullen (2006).

In relation to the factors that are conditions precedent for the ICM practice, also analyzed by Souza (2008) in an empirical study in the corporate service segment, by Camacho (2010) in the hospital segment, and by Facci (2011) in the Information Technology industry, the following evidence was obtained, as in Chart 2 below:

\begin{tabular}{|l|c|c|}
\hline Conditions precedent & Characteristics & Potential to ICM \\
\hline \multirow{3}{*}{ Products } & Profit margin & Low \\
\hline \multirow{4}{*}{ Components } & Functionality & High \\
\hline \multirow{4}{*}{ Relationship level } & Technology & High \\
\cline { 2 - 3 } & Value index & Low \\
\hline \multirow{4}{*}{ Types of chain } & Common & Low \\
\cline { 2 - 3 } & Ancillary & High \\
\cline { 2 - 3 } & Principal & High \\
\cline { 2 - 3 } & Familiar & High \\
\hline \multirow{3}{*}{ Mechanisms } & Tyranny & Low \\
\cline { 2 - 3 } & Oligarchy & Low \\
\cline { 2 - 3 } & Democracy & High \\
\cline { 2 - 3 } & Disciplining & High \\
\cline { 2 - 3 } & Enabling & High \\
\cline { 2 - 3 }
\end{tabular}

CHART 2 - Factors that are conditions precedent to ICM in the assembly plant surveyed

Source: Authors.

In Chart 2, as developed by Souza (2008) and pointed out in Chart 1 of this paper, two aspects can be observed in analyzing item "Product": profit margin and functionality. The profit margin for suppliers and the assembly plant is close to what was expected, as the assembly plant adjusts parameters by item with the suppliers, such as hour/MOD.

In analyzing the profitability of suppliers, suppliers are accepted to have in the region of 5\% Operating Profit and 10\% Return on Investment. Margins that are high or within expectations mean low potential for ICM application, which is more applicable when products have low margins, according to Kajüter and Kulmala (2005).

According to the surveyed executives, application of the Target Costing and Kaizen Costing, suggested by Seuring and Goldbach (2002), is a practice used by the assembly plant and encouraged in its major suppliers in order to reduce costs and expand the possibility of more attractive profit margins. The functionality of the product or service is related to its specifications. 
With the process to produce modules or systems, products delivered by the suppliers to the assembly plants not only increase their value added, but also expand their functionalities. The parts that are usually delivered individually become part of a more complete module or system, which will be delivered directly in the production line. In this case, we evidence that the ICM practice exists, according to Cooper and Slagmulder (1999), as the assembly plant and its suppliers work together to improve their margins and expand the functionality of products and services demanded over the production process.

As for the components, the ICM should be applied only for key components, considering the technology level and value index, as mentioned by Souza and Rocha (2009). Both the assembly plant and its major suppliers have a high level of technological development, which enables ICM application.

The value index includes the component importance level and its cost, i.e., it is a component's cost-effectiveness relationship. The assembly plant acquires structured modules with several parts or components from its suppliers and, therefore, this analysis was compromised due to the lack of information on the costs of each component and the level of significance.

The level of relationship between the assembly plant surveyed and its major suppliers can be characterized as Principal, as it has a high level of stability and reliability between those involved, in addition to a number of benefits with the sharing of information with the assembly plant since product development, which favors the implementation of the ICM in this SC, as mentioned by Mouritsen and Thrane (2006).

The type of chain is based on the number of companies dominating the chain, as mentioned by Souza and Rocha (2009). The chain studied can be characterized as Tyranny, characterized by the aforementioned economic power of Porter (1989). Suppliers can participate in the development of new products and are called to discuss costs and technology, but the final decision lies with the assembly plant, which does not share its economic and financial information with the suppliers. This type of chain offers more conditions for the ICM practice.

Mechanism types are classified as: Disciplining and Enabling, as advocated by Kajüter and Kulmala (2005). This study identifies the existence of budget preparation and cost spreadsheet developed by suppliers in conjunction with the assembly plant, in addition to information reliability agreements, which reinforce the interorganizational relationships, as mentioned by Dekker (2004).

As mentioned above, spreadsheets are broken down by $90 \%$ to $95 \%$ of the relationships between the assembly plant and its major suppliers. The assembly plant analyzes both accounting aspects and qualitative aspects of these relationships and these are examples of mechanisms that can evidence the ICM practice, as it makes no sense for companies to exchange detailed information if they are not adopting the ICM, as mentioned by Coad and Cullen (2006) and Agndal and Nilsson (2009).

\section{CONCLUSIONS}

We believe that the general objective of this research was achieved, as we detected that the Interorganizational Cost Management is adopted in an automotive assembly plant in the Greater Region of ABC. The assembly plant surveyed requires clear transparency of information from its suppliers and strengthens its relationship with them through this practice. Suppliers share not only information with the assembly plant, but also employees and investments, as advocated by the ICM, as developed by Cooper and Slagmulder (1999).

This research provides indications that the assembly plant surveyed has a partnership relationship with its first-level suppliers, and even shares employees (of technical level) with them to meet joint solutions.

The participation of suppliers in the development process of new products and their collaboration in cost and technology discussions, with the final decision lying with the assembly 
plant, characterizes this chain as a Tyranny and allows the ICM adoption. This study provides indications that the Tyranny relationship, in which the SC is led by the assembly plant, aims at operational efficiency, in terms of cost and development of products, and is interesting and benefiting to the parties involved, as mentioned by Cooper and Slagmulder (1999).

We can conclude that the relationship between the assembly plant and its suppliers is will integrated and presented a high level of stability and reliability, which indicates that such relationship became more stable and long standing, and that sustainability of operations in the SC have been kept. In this regard, the results of this research are in conformity with those reported by Myers and Cheung (2008), upon arguing that interests in common lead to the formation of strategic alliances between parties of the SC.

We detected that the automotive industry investigated has a well-defined relationship with the SC members, which facilitates information exchange, whether operational, economic or financial information, and allows ICM operationalization.

This research reveals that focus on Strategic Cost Management and the use of new opportunities are factors that influence companies and to form alliances or networks. For the proper functioning of these interorganizational relationships, information flow is needed, so as to allow cooperation between the parties, as mentioned by Caglio and Ditillo (2008).

A limitation of this exploratory research is the data collection method. We opted for a single source of data: personal inquiries of executives of several functions at a major multinational automotive manufacturer. The main limitation of the research conducted lies in the failure to use other sources of information for internal validation, through triangulation with first-level suppliers, for example.

As mentioned above, the ICM is a significant tool to generate benefits to the companies participating in a SC, which represents a source of competitive advantage to individual companies and to the interorganizational network. This tool establishes approaches in connection with cost reduction, and using it become a strategy, and should be included in the companies' planning.

As regards recommendations for future research, we suggest that researchers:

1) expand the number of respondents in the automotive industry supply chain, i.e., expand the sources of information to increase internal validity, through triangulation of data with firstlevel suppliers - auto parts or system companies - in order to prove what has been evidenced by the assembly plant executives;

2) check whether the interorganizational relationship with its customers (concessionaires) has any kind of economic and financial information sharing by the assembly plant, and

3) replicate the research in other segments to check whether the ICM is adopted in them, and how it is implemented in the several types of interorganizational relationships in other segments of the Brazilian and international economy.

Thus, our findings in this research corroborate the proposals of Cooper and Slagmulder (1999) and other researchers, such as Souza (2008), Souza and Rocha (2009), Camacho (2010) and Facci (2011), among others, that the interorganizational relationship and the ICM are intended to explore new opportunities and minimize costs in the SC or in the business network.

We consider that this research, which aimed to check how the Interorganizational Cost Management has been adopted in a multinational automotive manufacturer, contributes to the construction of knowledge in the fields of Management and Accounting as it integrates knowledge of Supply Chains, Business Networks, Interorganizational Relationships and Strategic Cost Management.

\section{REFERENCES}

AGNDAL, H.; NILSSON, U. Different open book accounting practices for different purchasing 
strategies. Management Accounting Research, London, v. 21, n. 1, p. 147-166, Sept. 2010.

Interorganizational cost management in the exchange process. Management Accounting Research, London, v. 20 , n. 1 , p. $85-101$, June 2009 .

Supply chain decision-making supported by an open books policy. International Journal of Production Economics, Amsterdam, v. 116, n.1, p. 154-167, Nov. 2008.

AGUIAR, A. B.; REZENDE, A. J; ROCHA, W. Uma análise da complementaridade entre gestão interorganizacional de custos e open-book accounting. BASE - Revista de Administração e Contabilidade, São Leopoldo, v. 5, n. 1, p. 6676, jan./abr. 2008.

AMATO NETO, J. Redes de cooperaçáo produtiva e clusters regionais: oportunidades para as pequenas e médias empresas. São Paulo: Atlas, 2000.

BISBE, J.; BATISTA-FOGUET, J.; CHENHALL, R. Defining management accounting constructs: a methodological note on the risk of conceptual misspecification. Accounting, Organization and Society, [S.1.], v. 32, n. 7-8, p. 789-820, Oct./ Nov. 2007.

BITTI, E. J. S.; AQUINO, A. C. B.; PAGLIARUSSI, M. S. Custos interorganizacionais: o efeito dos custos de monitoramento na decisão de mix de redes franqueadas Brasileiras. In: CONGRESSO USP DE CONTROLADORIA E CONTABILIDADE, 7., 2007, São Paulo. Anais... São Paulo: USP, 2007.

BORINELLI, M. L.; ROCHA, W. Análise estratégica de cadeia de valor: um estudo exploratório do segmento indústria-varejo. Revista Contemporânea de Contabilidade, Florianópolis, v. 4, n. 7, p. 145-165, 2007.

BOWERSOX, D. J.; CLOSS, D. J.; COOPER, M. B. Supply chain logistics Management, New York: McGraw-Hill/Irwin, 2002.
CAGliO, A.; Ditillo, A. A review and discussion of management control in inter-firm relationships: achievements and future directions. Accounting, Organization and Society, [S.1.], v. 33, n. 7-8, p. 868-898, Oct./Nov. 2008.

CAMACHO, R. R. Fatores condicionantes da gestáo de custos interorganizacionais na cadeia de valor de hospitais privados no Brasil: uma abordagem à luz da teoria da contingência. 2010 . 216 f. Tese (Doutorado em Ciências Contábeis)Faculdade de Economia, Administração e Contabilidade, Universidade de São Paulo, São Paulo, 2010.

CARMO, L. F. R. S.; HAMACHER, S. A evolução da cadeia de suprimentos da indústria automobilística no Brasil. Revista de Administração Contemporânea - RAC, Rio de Janeiro, v. 5, n. 2, p. 201-220, maio/ago. 2001.

CASTELLS, M. A sociedade em rede. 5. ed. São Paulo: Paz e Terra, 2001. (A era da informação: economia, sociedade e cultura; v. 1).

CHILDERHOUSE, P. et al. Information flow in automotive supply chains: identifying and learning to overcome barriers to change. Industrial Management \& Data Systems, [Shreveport], v. 103, n. 7, p. 491-502, 2003.

COAD, A.F.; CULLEN, J. Interorganizational cost management: towards an evolutionary perspective. Management Accounting Research, London, v. 17, n. 4, p. 342-369, Dec. 2006.

COKINS, G. Measuring costs across the supply chain. AACE International Transactions, Morgantown, 2000.

COOPER, R.; SLAGMULDER, R. Strategic cost management: expanding scope and boundaries. Journal of Cost Management, New York, v. 17, n. 1, p. 23-30, Jan./Fev. 2003. for the lean enterprise: interorganizational cost management. New Jersey: The IMA Foundation for Applied Research, 1999. 
Cost management beyond the boundaries of the firm. Management Accounting Research, London, v. 79, n. 9, p. 18-20, 1998.

; YOSHIKAWA, T. Inter-organizational cost management systems: the case of the Tokyo-Yokohama-Kamakura supplier chain. International Journal of Production Economics, Amsterdam, v. 37, n. 1, p. 51-62, Nov. 1994.

COX, A; SANDERSON, J.; WATSON, G. Supply chains and power regimes: toward an analytic framework for managing extended networks of buyer and supplier relationships. The Journal of Supply Chain Management, [S.1.], v. 37, n. 1, p. 28-35, Mar. 2001.

CRESWELL, J. W. Projeto de pesquisa: métodos qualitativo, quantitativo e misto. 3. ed. Porto Alegre: Bookman, 2010.

DEKKER, H. C. Value chain analysis in interfirm relationships: a field study. Management Accounting Research, London, v. 14, n. 1, p. 1-23, Mar. 2003.

Control of inter-organizational relationships: evidence of appropriation concerns and coordination requirements. Accounting, Organizations and Society, [S.1.], v. 29, n. 1, p.27-50, Jan. 2004.

DUBOIS, A. Strategic cost management across boundaries of firms. Industrial Marketing Management, New York, v. 32, n. 5, p. 365-374, July 2003.

FACCI, N. Um estudo sobre características dos fatores contingenciais na gestáo de custos interorganizacionais em um arranjo produtivo local do setor de tecnologia da informaçáo na regiáo noroeste do Paraná. 2011. 106 f. Dissertação (Mestrado em Contabilidade)Universidade Federal do Paraná, Curitiba, 2011.

FARIA, A. C. et al. Gestão de custos interorganizacionais (GCI) e contabilidade de livros abertos (CLA): investigação bibliométrica com ênfase em periódicos internacionais e nacionais. In: CONGRESSO BRASILEIRO DE CUSTOS, 17., 2010, Belo Horizonte. Anais... Belo Horizonte: Associação Brasileira de Custos, 2010.

GIANIASELLA, R. L. G.; SOUZA, M. A.; ALMEIDA L. B. Adoção de alianças estratégicas por empresas dos pólos calçadistas do Vale do Rio dos Sinos-RS e de Franca-SP: um estudo exploratório. Revista Brasileira de Gestáo de Negócios - RBGN, São Paulo, v. 10, n. 26, p. $45-62$, jan./mar. 2008 .

GIL, A. C. Métodos e técnicas de pesquisa social. 7. ed. São Paulo: Atlas, 2008.

Estudo de caso: fundamentação científica, subsídios para coleta e análise de dados e como redigir o relatório. São Paulo: Atlas, 2009.

GOLDBACH, M. Organizational settings in supply chain costing. In: SEURING, S.;

(Ed.). Cost management in supply chains. New York: Physica-Verlag, 2002. p. 89-110.

HAKANSSON, H.; LIND, J. Accounting and network coordination, Accounting, Organizations and Society, [S.1.], v. 29, n. 1, p. 51-72, Jan. 2004.

HOLWEG, M. et al. Supply chain collaboration: making sense of the strategy continuum. European Management Journal, Oxford, v. 23, n. 2, p. 170-181, Apr. 2005.

KAJÜTER, P.; KULMALA, H. Open-book accounting in networks: potencial achievements and reasons for failures. Management Accounting Research, London, v. 16, n. 1, p. 179-204, June 2005.

KULMALA, H.; KAJÜTER, P.; VALKOKARI, $\mathrm{K}$. Inter-organizational cost management in $S M E$ networks. In: MANAGEMENT ACCOUNTING RESEARCH: COST AND PERFORMANCE MANAGEMENT IN SERVICES AND OPERATIONS, 8th., 2007, Trento. 
Proceedings... Brussels: European Institute for Advanced Studies in Management, 2007.

; PARANKO, J.; UUSI-RAUVA. E. The role of cost management in network relationships. International Journal of Production Economics, Amsterdam, v. 79, n. 1, p. 33-43, Sept. 2002.

LAMBERT, D. M; GARCIA-DASTUGUE, S. J.; CROXTON, K. L. An evaluation of processoriented supply chain management frameworks. Journal of Business Logistics, [S.1.], v. 26, n. 1, p. 25-51, 2005.

LORANDI, J. A. Sistemática de implementaçáo do custeio-alvo na cadeia de suprimentos com o uso do desdobramento da funçáo qualidade (QFD). 2009. 204 f. Tese (Doutorado em Engenharia de Produção)-Universidade Federal de Santa Catarina, Florianópolis, 2009.

MYERS M. B.; CHEUNG, M. S. Sharing global supply chain knowledge. MIT Sloan Management Review, Cambridge, v. 49, n. 4, p. 67, July 2008.

MONDEN, Y. Sistemas de reduçáo de custos: custo alvo e custo kaizen. Porto Alegre: Bookman, 1999.

MOURITSEN J.; HANSEN A.; HANSEN, C. Inter-organizational controls and organizational competencies: episodes around target cost management/functional analysis and open book accounting. Management Accounting Research, London, v. 12, n. 2, p. 221-244, June 2001.

; THRANE, S. Accounting, network complementarities and the development of inter-organizational relations Accounting, Organizations and Society, [S.1.], v. 31, n. 3, p. 241-275, Apr. 2006.

NASCIMENTO, S.; PEREIRA, A. P. Gestão de custos interorganizacionais em transportadora de carga fracionada. In: SIMPÓSIO DE ADMINISTRAÇÃO DA PRODUÇÃO, LOGÍSTICA E OPERAÇÓES INTERNACIONAIS - SIMPOI. 14., 2011. Anais... São Paulo: [FGV], 2011.
PONTE, V. M. R. et al. Análise das metodologias e técnicas de pesquisas adotadas nos estudos brasileiros sobre balanced scorecard: um estudo dos artigos publicados no período de 1999 a 2006. In: CONGRESSO DA ASSOCIAÇÃO NACIONAL DOS PROGRAMAS DE PÓSGRADUAÇÃO EM CIÊNCIAS CONTÁBEIS 1., 2007. Anais... São Paulo: Anpcont, 2007.

PORTER, M. E. Vantagem competitiva: criando e sustentando um desempenho superior. Rio de Janeiro: Elsevier, 1989.

RICHARDSON, R. (Coord.) Pesquisa social: métodos e técnicas. 3. ed. São Paulo: Atlas, 1999.

SEURING, S. Supply chain target costing: in apparel industry case study. In:

GOLDBACH, M. (Ed.). Cost management in supply chains. New York: Physica-Verlag, 2002. p. 111-126.

; GOLDBACH, M. (Ed.). Cost management in supply chains. New York: Phisica-Verlag, 2002.

SHANK, J. K; GOVIDARAJAN, V. A revoluçáo dos custos: como reinventar e redefinir sua estratégia de custo para vencer em mercados crescentemente competitivos. Rio de Janeiro: Elsevier, 1997.

SIMMONDS, K. Strategic management accounting. Management Accounting, [S. 1.], v. 59, n.4, p. $26-29,1981$.

SOUZA, B. C. Fatores condicionantes da gestão de custos interorganizacionais. 2008. $141 \mathrm{f}$. Dissertação (Mestrado em Controladoria e Contabilidade)-Faculdade de Administração, Economia e Contabilidade, Universidade de São Paulo, São Paulo, 2008.

; ROCHA, W. Gestáo de custos interorganizacionais: açóes coordenadas entre clientes e fornecedores para otimizar resultado. São Paulo: Atlas, 2009. 
STURGEON, T.; BIESEBROECK, J. V.; GEREFFI, G. Value chains, networks and clusters: reframing the global automotive industry. Journal of Economic Geography, Oxford, v. 8, n. 3, p. 297-321, Apr. 2008.

WOMACK, J. P.; JONES, D. T.; ROOS, D. A máquina que mudou o mundo. 8. ed. Rio de Janeiro: Campus, 2004.
XAVIER, M. L. P.; SOUZA, A. C. M.; BRESCIANI, L. P. O novo perfil econômico do grande ABC. Organizaçóes em Contexto, São Paulo, v. 3, n. 6, p. 103-122, jul./dez. 2007. 